\title{
Cultural Communication in Social Integration between Bawean Ethnic and Malay Sub-Ethnic in Malaysia
}

\author{
Muhammad Ridhwan Sarifin \\ Senior Lecturer \\ Department of Social and Citizenship Studies (JPKK). \\ Faculty of Human Sciences (FSK). Sultan Idris Education University (UPSI), \\ 35900 Tanjong Malim Perak Darul Ridzuan, MALAYSIA
}

\begin{abstract}
Cultural communication has obliquely shapes society relationships with another for the sake of togetherness prosperity. Diversity of norms and values from cultural symbols are able to be transferred as connecting elements in order to create interaction that is based on mutual comprehension of cultural norms. This study objective is to comprehend Bawean ethnic's cultural communication symbol. Employing qualitative methods, social construction paradigm is perceived through in-depth interview. This methodology adapted to realize the meaning of cultural communication between Bawaean and the other Malay sub-ethnicity. There are one main informant and ten other informant whom have been interviewed face-to-face. The result has shown that Bawean ethnic's cultural communication symbol such as language, cuisine, martial arts and religious rituals are the main elements in Bawean ethnic's cultural communication. In conclusion, cultural communication between Bawean ethnic and other ethnic has taken place according to the situations as either inside or outside the group. Cultural similarities has facilitate cultural communication tranquility. It creates social integration with relation to the ethnic relationship processes such as acculturation, accommodation and integration.
\end{abstract}

Keywords: cultural communication, social integration, Bawean ethnic, material culture, non-cultural material, Malaysia.

\section{Introduction}

According to sociological dictionary (2005), communication involves the process of creating meaning which is established in all social situations. Cartier \& Hanvood (1953) has defined communication as "shifting ideas from someone to another". Giddens \& Sutton (2014) also has conceptualized culture as a comprehensive learned element in way of life such as language, value, social norm, beliefs, customs and laws. In addition, Giddens \& Sutton stated that it is also bound to social relationships. Communication is furthermore a procees that allows someone to convey stimulation in order to change anothers behavior (Mulyana, 2010). According to Onong Uchjana Effendy (1986), there are three main purposes in communication which are; firstly, the receiver understood the message given, secondly, message receiver must be determined and thirdly, it motivates action through the given message. Thus, communication is proven to be influencing in shaping receiver's culture that operates culture together through social interaction.

Therefore, it is perceived that cultural communication is a way to comprehend a cultural symbol property inside or outside of the group in order to build mutual understanding. This will led to harmonious social interaction if the cultural communication distribution are acceptable to all parties either the receiver or the presenter. Social interaction can be perceived through cultural communication effectiveness when a society group can comprehend the culture of one another. Cultural communication can be seen as an effort in order to ensure harmonious life of a society. Indirectly, culture has been influencing communication to ensure

Muhammad Ridhwan Sarifin, IJSRM Volume 08 Issue 01 January 2020 [www.ijsrm.in] SH-2020-585 
society's action as according to their motivation such as respecting each other and maintaining prosperity. The society acts upon communication based on three main cultural social elements which are the belief system, values and attitudes (Edwin et al., 2010). These three elements have also encounter the perception process. According to Edwin et al., perception is a crucial communication aspect between culture because the society from different culture often perceived that theirs are different. Thus, it is important to realize that the three elements are relevant to stimulate each comprehension to avoid cultural conflict. Cultural communication exists throughout the historic and geographic of one learned culture (Edwin et al., 2010).

Culture communication can be divided into two concepts which are symbol and language. Symbol is the mediator between material-shaped communication and non-material. For instance in Malaysia, the material symbols are architecture, apparel, cuisine and dance. Meanwhile one of the example in non-material cultural symbol is gotong-royong. Language here acts as one of the agents in communication as one of social bound strategies in order to prevent conflict or misunderstanding. One mutual perceived language by a society will prevent misunderstanding or even hatred upon one's society. For instance, Malaysia which has diversity of races without one common language can create misunderstanding in daily life and can cause limited social interaction.

Social interaction has become a catalyst in cultural communication due to the society's realization and understanding of each's roles to ensure each of its members will not contribute into any conflict. The strategies in ensuring social interaction went well in cultural communication are by realizing the processes in ethnic relationships such as integration, accommodation, amalgamation and acculturation. Mohamad Fauzi Sukimi (2010) explains the process of ethnic relationship as one of the social modals that enables a society to learn culture at the communication process. It can comprehend one's language, cuisine, apparel and togetherness value. Cultural communication cannot be separated from human's daily life because each individual are born according to one's communities. Thus, human will learn ways of communication for their survival and next, they will preserve their culture such as their mother tongue.

\section{Objective of study:-}

This paper attempts to comprehend Bawean ethnic's cultural communication symbol that consists of language, cuisine, martial arts (silat) and its leader in creating social interaction with Malay sub-ethnic to avoid communication conflict.

\section{Methodology:-}

This study has employed qualitative measure in methodology of in-depth interview and observation is not adapted upon Bawean as one of the sub-ethnic in Malaysia. Data analysis is supported by former studies. A total of seven man and four women are interviewed.

\section{Findings:-}

\section{Bawean ethnic's cultural communication symbol}

Bawean communication symbol in Malaysia has been realized by cultural retention. Bawean has been holding up towards their ancestors customs in order to retain their culture as well as customs no matter where they go (Media Bawean, April 2011). This is due to the fact that Bawean has strong perseverance on their true identity. Majority of the findings in the interview conducted between February 2017 until December 2017 has revealed that Bawean prefers to be known as Bawean than Malay when interacting with the Malay. The elements that contribute towards their preferences are their language, cuisine, martial arts and leader. Thus, it is identified as a cultural communication manifestation in order to avoid conflict.

\section{i) Language}

In the Bawean history, Jawa Kuno language has become the significant event due to the fact that the establishment of civilization were there before the emergence of Majapahit governance. Civilization is established in Bawean Island in the introduction of honocoroko alphabets as a result of Buddhist teaching practiced by Raja Aji Soko (Dhiyauddin Qushwandhi 2008). The historical evidence can be seen at the Lebak village, Sangkapura. Inscriptions of honocoroko were found in the shape of carved stones. Honocoroko is one of the kuno writings as a result of Sanskrit alphabets modifications. The writing has 
similar features with the alphabets systems around Asia especially Thailand, Myanmar and India. Raja Aji Soko has significant roles in the history of Bawean Island as it is indirectly bring up itw own identity in Bawean Island chronological history.

In general, Jawa-Kuno language is Bawean language before the existence of preachers language which is the Madura language. This particular language has bring some impact to the Bawean language until there is a language mixture that brings evolution until today (Zulfa Usman 1992). Bawean language has different vocabulary and phrases with Bahasa Melayu although it also has some similarities. The writings of Bawean $\&$ Bahasa Melayu are using the same roman writing. Yet, there are subtle language and common languange among Bawean language. From the frequency of Bawean language usage among them, it has been realized that eight of the informants are almost using Bawean language in total in the interview interaction. Meanwhile in researcher observation, communication in Bawean language is also exists between the elders and the children of Bawean. In overall, the interview sessions have revealed that Bawean language is a significant matter for them because their usage of the language could enhance the trust amongst them and it also symbolize their identity coherence.

\section{ii) Cuisine}

Each ethnicity has their own signature cuisine as cultural symbol which consist in material culture. Cuisine has its own identity such as traditional cuisine. Cuisine as onethe of the potential human thinker has caused cuisine not only function as energy provider but also helps protecting the body systems (Ahmad Hakimi Khairuddin \& Wan Abdul Kadir Wan Yusof 2006). They stated that cuisine is the source of sustainable life in order to help the coherence of society life. It is common for the Bawean to have the cuisine of kuah coley and kuah asam. The cuisine basically is a common dish for Bawean. Tuna has been Bawean menu priority in their cuisine. The arrival of man followed by women into Malaysia has made this dish a main course in cuisine. Indirectly, the dish has reflected Bawean identity. The perfect life in Malaysia has made them prepared this dish daily at home for the whole family.

It is approved by the interview informant in their in-depth interview session as it is easy to cook as it is easily accessible in Malaysia. One of them has also stated that Bawean cuisine has always have been the choices of Bawean in their serving of Bawean events and celebrations. The women are specifically trained to cook Bawean cuisine. Bawean cuisine is always have been their special identity as a true blood of Bawean and it has its own significant meaning for them. It is supported by the other interview informant as they frequently ate Bawean cuisine. They also has a dish named ghedhung which is made of poisonous fruit skin after being cleaned using natural resources such as river water and charcoal ashes. It is the sentiment identity of Bawean because it will be bring together as souvenirs to the one that lives in Malaysia. Their cuisine has been well maintained in their daily life as Bawean take care of their heritage and tradition to be developed by the future generations.

\section{iii) Martial Arts}

Bawean ethnic has martial arts known as pencak silat and silat pokolan. According to the poem of Zulfa Usman (1992), the skills of pencak silat is a significant element as a true Bawean. Pencak silat is a guidance for a man as masculinity is significantly respected. It has what it called as jurus in different levels as it is also different according to its teacher as it is a combined martial arts knowledge of China and Tanah Jawa. The performance of it is usually accompanied by drums as two man played it and one man played gong. The first act is performed by a man thus next act as referee who performed the jurus with two swords. Next, It will be passed on to two warriors who will fight wearing special Malay apparel (as cultural element of Bawean island) with a rolled sarung songket. Before the fight, the warrior will perform the beauty of their own jurus (Ahmad Muzakki 2015).

During the interview at the research area, the findings revealed that silat pencak can be performed by all seven man informant interview. It is learned formally with a silat master every end of month with duration of four hours lesson. Informant alsoand stated that they were involved in the events and celebrations such as weddings and cultural events. They explained that it is an identity needed to be preserved because it involves a lot of related spiritual practices such as abstinence of self as well as emotions.. 


\section{iv) Leader}

Bawean history has shown than Bawean are very loyal and obey their leader. It has started with a leader named Maulana Umar Mas'ud which brings new changes of life in relation to faith and religion (Dhiyauddin Qushwandhi 2008). From his historical record, an individual who manage administration from the aspects of politics, social and economy known as kiai. From social stratification, kiai is at the highest level. Kiai criteria to represent an area of placement of Bawean are; wide religious knowledge, able to advice the whole community and from the descendants of kiai. Kiai influence is significant to ensure the community upholding the advices or jurisdiction given. Kiai nowadays is still have their own roles in Bawean affairs.

Vredenbregt (1990) has explained several main duty and services of kiai and it is listed as follows i;to give purified water or spelled water to the villagers whom faced genie distraction, ii; to lead prayer recitation on weddings events, new houses and departure events of Bawean to Bawean Island, iii; to give name for the newborns, iv; to pick suitable weddings date, or celebration events for the villagers. In the interview, all of these roles were confirmed by informants as kiai will lead to start the event. Other than that, kiai leads as imam in congregational daily prayer and not Jumaat prayer only. The informant explained that most of kiai roles are related to advices and necessity in which needed to be fulfilled by Bawean so that no problems occur. For example, upholding good name of Bawean and helping each other in gotong-royong. In national context, local leader has the authority as the main patron of education welfare, land and licensing ownership as well as the others as acknowledged by the Malay or even Malaysian.

\section{Discussion:-}

According to the findings, Bawean cultural communication symbols as one of the sub-ethnic are revealed through the ethnic relationships processes in facing other Malay sub-ethnic as stated in Table 1 below:

Table 1: Cultural Communication Symbol

\begin{tabular}{|l|l|l|l|}
\hline $\begin{array}{l}\text { Cultural } \\
\text { Communication } \\
\text { Symbol }\end{array}$ & Bawean & Malay Sub-Ethnic & $\begin{array}{l}\text { Ethnic } \\
\text { Relationship } \\
\text { Process }\end{array}$ \\
\hline Language & Bawean Language & National Language & Accommodation \\
\hline Cuisine & $\begin{array}{l}\text { Special Bawean } \\
\text { Cuisine }\end{array}$ & Malay Traditional Cuisine & Acculturation \\
\hline Martial Arts (Silat) & Pencak Silat & $\begin{array}{l}\text { Silat Gayong Fatani/ } \\
\text { Silat Cekak Hanafi }\end{array}$ & Accommodation \\
\hline Leader & Kiai & $\begin{array}{l}\text { Chief of Village/ } \\
\text { Representative of People/ } \\
\text { Local Authorities }\end{array}$ & Integration \\
\hline
\end{tabular}

Bawean culture in the above table has shown that there are ethnic relationships processes in which allows Bawean cultural communication symbols to be assimilated into the other Malay sub-ethnic across states in Malaysia. The transfer can be divided into criterias as shown below:

1. Language is one of the interaction medium either within the ethnic or non-ethnic. One common national language is adapted in order to communicate efficiently with the non-ethnic (out group). The process of accommodation has easily take place due to the fact that there are similarities in vocabulary. This process has enable an understanding in the usage of bahasa Melayu by both parties even they are different in ethnicity.

2. Cuisine has become a significant aspect of Bawean and Malay life because its is fixed based on the religion laws. Bawean also has no problem adapting into sub-ethnic Malay cuisine as it has Nusantara elements similarities. Thus, acculturation has take place in the way of preparing the meal or enjoying it.

3. Silat as one of the most significant martial arts has made Bawean and the Malay to embrace similarities in silat identification highlights. Accommodation has take place in pencak silat that 
originates from Bawean and the other silat that is evolving in Malaysia. Bawean pencak silat performance can be observed through their performing instruments such as weapon, apparel, accompaniment music that is also reflects Malay culture.

4. Leader has become the institutional patron in the social system which has made the Baweanfact obey the rules as community members and population under one government. Leader are meant to be obeyed based on situation as life coherence and to be acknowledged as a part of the citizens. This is where integration take place as leader has the authority along the official business.

Sanggar (2012) has explained that in order to avoid communication conflict, this indication must be applied such as believing the institutions in shaping integration values. He also explained that the Britain and non-Britain has always respecting the reserved rights together and remain their words so that they will not offend others in their daily life. It is crystal clear that language has become the medium to abolish prejudice.

Macpherson (2005) has also stated that the new legislation "new race" in New Zealand has ensure the welfare and security of the future. The situation forced the aborigines and the new citizen to accept acculturation policy to overcome cultural communication problems. The policy succeed upon both parties as culture, language and land ownership are protected by the government. This shows that cultural tolerance will ensure cultural communication coherence so that life well-being are accomplished together. Indirectly, it is also brighten cultural colors of a country.

\section{Conclusion:-}

Each country has own cultural didiversity that covers all types of races as well as ethnicity. This cultural diversity is a manifestation of cultural communication in which has resulted social integration. Each ethnicity will act upon accepted message in order to strengthen social interaction due to the fact that there is mutual understanding to share values to be upheld together. Each ethnicity has their own identity to be developed in order to sustain social relationships. Thus, cultural communication between sub-ethnic study and even on the level of race is essential for the prospering country in diversity ethnic integration in order to identify diversity in cultural communication as well as the processes in each ethnicity especially for the multiracial society. These elements must be examined, identified and revealed its content in depth and ongoing manner.

\section{References}

[1] Ahmad Hakimi Khairuddin \& Wan Abdul Kadir Wan Yusof. (2006). Makanan Dalam Masyarakat Dan Budaya Melayu: Pengumpulan Perkataan Untuk Kamus Sebagai Pelestarian Warisan Seni Budaya Melayu. Prosiding Persidangan Antarabangsa Pengajian Melayu. Universiti Malaya. Kuala Lumpur.

[2] Ahmad Muzakki. (2015). Menelisik Eksistensi Pencak Silat Bawean. Sebuah Kajian historis sebagai Aset Budaya Lokal. http://www.bawean.net/2015/02/menelisik-eksistensi-pencak-silat-bawean.html. Accessed on: 9 June 2018.

[3] Cartier F. A. \& Hanvood K. A. (1953) On Definition of Communication. Journal of Communication. Volume 3, Issue 2, November. Pages 71-75. https://doi.org/10.1111/j.1460-2466.1953.tb01076.x.

[4] Dhiyauddin Qushwandhi. (2008). Waliyah Zainab: Puteri Pewaris Syeikh Siti Jenar. Sejarah Agama dan Peradaban Islam di Pulau Bawean. Penyusun: Abdullatif Hasbullah \& Ali Masduqi Afgan. Yayasan Waliyah Zainab Diponggo. Bawean. Gresik. Jawa Timur. Indonesia.

[5] Edwin R. Mcdaniel, Larry A. Samovar, Richard E. Porter. (2010). Using Intercultural Communication: The Building Blocks. Intercultural Communication: A Reader, Thirteenth Edition. . Wadsworth, Cengage Learning. United States America.

[6] Macpherson Cluny. (2005). Reinventing the Nation: Building a Bicultural Future from a Monocultural Past in Aotearoa/New Zealand. In. Paul Spickard. (pnyt.) Race and Nation. Ethnic System in The Modern World. Routledge Taylor \& Francis Group. New York.

[7] Media Bawean. (2011). Kuat Pegang Adat Istiadat. http://www.bawean.net/2011/04/ kuat-pegangadat-istiadat.html. Accessed on: 6 July 2018. 
[8] Mohamad Fauzi Sukimi. (2010). Migrasi dan Pembentukan Identiti Majmuk: Orang Madura di Kampung Teras Jernang. Bangi, Selangor. Doctorate Thesis. Universiti Kebangsaan Malaysia.

[9] Mulyana A. Z. (2010). Rahasia Menjadi Guru Hebat Memotivasi Diri Menjadi Guru Luar Biasa. Jakarta: PT Gramedia. Indonesia.

[10] Onong Uchjana Effendy. (1986). Ilmu komunikasi. Teori dan Praktek. Penerbit Remadja Karya CV Bandung. Indonesia.

[11] Saggar Shamit, Will Somerville, Rob Ford \& Maria Sobolewska. (2012). The Impacts of Migration on Social Cohesion and Integration. Final report on the Migration Advisory Committee. https://assets.publishing.service.gov.uk/government/uploads/system/uploads/ attachment_data/file/258355/social-cohesion-integration.pdf. Accessed on: 8 May 2018.

[12] Scott John \& Marshall Gordon. (2005). Oxford Dictionary of Sociology. (edt.) $3^{\text {rd }}$ Edition. Oxford University Press Inc., New York.

[13] Vredenbregt Jacob. (1990). Bawean dan Islam. Indonesian Netherlands Cooperation in Islamic Studies (INIS). Jakarta. Indonesia.

[14] Zulfa Usman. (1992). Kisah-Kisah Pulau Puteri (Pulau Bawean). Foundation Perwakilan Bawean. Indonesia. 